\title{
Deoxygenation of Guaiacol and Woody Tar over Reduced Catalysts
}

\author{
Takehisa Mochizuki*, Shih-Yuan Chen, Makoto Toba, Yuji Yoshimura \\ National Institute of Advanced Industrial Science and Technology \\ Tsukuba Central 5, 1-1-1 Higashi, Tsukuba, Ibaraki 305-8565, Japan
}

\begin{abstract}
The effect of various reduced catalysts for the upgrading of bio-oil produced by fast
\end{abstract} pyrolysis in a small batch reactor was evaluated using reduced $\mathrm{Ni} / \mathrm{SiO}_{2}, \mathrm{Co} / \mathrm{SiO}_{2}, \mathrm{Pt} / \mathrm{SiO}_{2}$, $\mathrm{Pd} / \mathrm{SiO}_{2}$, and conventional sulfided $\mathrm{CoMo} / \mathrm{Al}_{2} \mathrm{O}_{3}$ catalysts. All of the reduced catalysts were prepared by incipient wetness impregnation. Hydrodeoxygenation (HDO) reactions carried out in the $\mathrm{H}_{2}$ pressure range of $1-5 \mathrm{MPa}$ and temperature range of $300-350{ }^{\circ} \mathrm{C}$ using guaiacol and woody tar as model compounds for fast pyrolysis oil demonstrated that at $300{ }^{\circ} \mathrm{C}$, higher guaiacol conversion was achieved with the reduced $\mathrm{Co} / \mathrm{SiO}_{2}, \mathrm{Ni} / \mathrm{SiO}_{2}$, and $\mathrm{Pd} / \mathrm{SiO}_{2}$ catalysts compared with the conventional sulfide $\mathrm{CoMo} / \mathrm{Al}_{2} \mathrm{O}_{3}$ catalyst. However, only the reduced $\mathrm{Co} / \mathrm{SiO}_{2}$ catalyst exhibited high $\mathrm{HDO}$ activity and selectivity towards aromatics in the guaiacol HDO reaction. The reduced $\mathrm{Co} / \mathrm{SiO}_{2}$ catalyst also exhibited high $\mathrm{HDO}$ activity and selectivity towards aromatics in the HDO of woody tar, indicating that this catalyst may be 
active for direct deoxygenation of phenol yielding mostly benzene. Thus, the reduced catalysts, especially the $\mathrm{Co} / \mathrm{SiO}_{2}$ catalyst, can be considered to be potential candidates for use as HDO catalysts with improved activity and selectivity.

Keywords: Hydrodeoxygenation, $\mathrm{Co} / \mathrm{SiO}_{2}$ catalyst, Pyrolysis oil, Bio-oil upgrading

\section{Introduction}

The use of renewable energy resources represents one of the best means of reducing the dependence on petroleum energy [1]. Biomass is renewable and available for use as biofuel throughout the world. Due to the negligible content of sulfur and ash, biomass is considered a clean energy source that produces less emission of harmful pollutants than conventional fossil fuels do. Biomass is also greenhouse gas neutral given that the $\mathrm{CO}_{2}$ emitted from fuels is recycled by photosynthesis. Several biomass conversion technologies have been proposed for producing biofuel, and some have already been commercialized. The existing techniques include fast pyrolysis followed by hydroprocessing, gasification followed by Fischer-Tropsch synthesis and hydroprocessing, and biochemical conversion using dilute acid pretreatment with simultaneous saccharification and co-fermentation. Recently, the fast pyrolysis process for producing bio-oil has gained special recognition because of its economic 
advantages relative to other biomass-to-liquid conversion processes such as gasification-FT synthesis (FT-oil) and biochemical (bio-ethanol) processes. Fast pyrolysis is economically advantageous because it requires a very short reaction time (a few seconds or less) and a moderate reaction temperature (around $500{ }^{\circ} \mathrm{C}$ ) [2]. However, bio-oils produced from fast pyrolysis cannot be used directly as transportation fuels because of their high oxygen (30-40 $w t \%)$ and water (15-30 wt $\%)$ contents. Further improvement of bio-oil is thus necessary prior to its practical application as transportation fuel $[3,4]$.

Hydrodeoxygenation (HDO) is a promising way to decrease the oxygen content of bio-oil. This reaction has conventionally been applied in conjunction with commercial hydrodesulfurization (HDS) catalysts, i.e., sulfided $\mathrm{CoMo} / \mathrm{Al}_{2} \mathrm{O}_{3}$ or $\mathrm{NiMo} / \mathrm{Al}_{2} \mathrm{O}_{3}$ catalysts [5]. These sulfided $\mathrm{CoMo} / \mathrm{Al}_{2} \mathrm{O}_{3}$ and $\mathrm{NiMo} / \mathrm{Al}_{2} \mathrm{O}_{3}$ catalysts are widely utilized in oil refineries during hydrotreatment processes. However, removal of sulfur from the active sites of these sulfide catalysts during the reaction [6] may result in product contamination, which is a major disadvantage to the use of these catalysts. Moreover, the catalysts must be continuously replenished with sulfur to prevent desulfiding and consequent loss of activity. In addition, the presence of sulfur-containing compounds has a negative impact on the reaction rate of deoxygenation owing to competitive adsorption of sulfur- and oxygen-containing compounds. 
Furthermore, the alumina $\left(\mathrm{Al}_{2} \mathrm{O}_{3}\right)$ support used with these catalysts is known to be active for coke formation [7-9] and unstable in the presence of large amounts of water $[10,11]$. Thus, water present in the pyrolysis oil along with the water generated during the HDO reaction may have an adverse effect on the lifetime of the catalyst [12,13]. In addition, compounds produced from the thermal degradation of lignin, such as guaiacol (2-methoxyphenol) and alkyl guaiacols, tend to form heavy hydrocarbons and coke, which reduce the activity of the catalyst $[9,14]$. Centeno et al. reported that the performance of the conventional catalysts can be improved by the use of a less acidic support such as active carbon or silica. The design of new catalysts that are active at the low temperatures needed to prevent coke formation is an alternative approach for the HDO of fast pyrolysis oils. The use of noble metal catalysts that can be prepared on supports such as silica $\left(\mathrm{SiO}_{2}\right)$, zirconia $\left(\mathrm{ZrO}_{2}\right)$, titania $\left(\mathrm{TiO}_{2}\right)$, and active carbon, all of which are more tolerant to water than $\mathrm{Al}_{2} \mathrm{O}_{3}$, is an attractive option $[15,16]$. Andrey and co-workers reported that carbon deposition on a silica-supported HDO catalyst was substantially lower than that on an alumina-supported HDO catalyst, thus silica-based supports should be considered as potential candidates for the design of HDO catalysts with improved stability [17]. However, one of the disadvantages of these noble metal catalysts is the requirement for high metal loadings to be active. In a previous study, it was demonstrated 
that the selectivity of both sulfided catalysts and noble metal catalysts for aromatic hydrocarbons, which are useful compounds for a high octane booster, was very low [18-24]. To achieve improved economic incentive, aromatic hydrocarbon selectivity, and stability, the design of new catalysts for the hydrotreatment of pyrolysis oil is highly desirable.

In the present study, the HDO reactions of the model compound, guaiacol (GUA) (which is a main component of bio-oil) and real woody tar are evaluated in the presence of several metal catalysts using a small batch reactor. In particular, the effects of metal species, the hydrogen pressure, and the guaiacol content on the HDO activity and selectivity are investigated with the objective of generating large amounts of aromatic hydrocarbon.

\section{Experimental}

\subsection{Catalyst preparation}

The monometallic $\mathrm{Co}, \mathrm{Ni}, \mathrm{Pd}$, and $\mathrm{Pt}$ catalysts investigated in this study were prepared by the pore-filling incipient wetness method. A $\mathrm{SiO}_{2}$ granule (Q-10; Fuji Silysia

Chemical Ltd., BET surface area: $192 \mathrm{~m}^{2} \mathrm{~g}^{-1}$, pore volume: $1.03 \mathrm{~mL} \mathrm{~g}^{-1}$ ) sample was sieved to yield a $150-250 \mu \mathrm{m}$ powder and calcined at $550{ }^{\circ} \mathrm{C}$ before use. The sieved $\mathrm{SiO}_{2}$ powder was then impregnated with the aqueous solution containing the metal precursor. The precursors 
were $\mathrm{Co}\left(\mathrm{NO}_{3}\right)_{2} \cdot 6 \mathrm{H}_{2} \mathrm{O}$ (Wako Pure Chemicals, purity: $>99.5 \%$ ), $\mathrm{Co}\left(\mathrm{CH}_{3} \mathrm{COO}\right)_{2} \cdot 4 \mathrm{H}_{2} \mathrm{O}$ (Wako

Pure Chemicals, purity: $>99.5 \%$ ), $\mathrm{Ni}\left(\mathrm{NO}_{3}\right)_{2} \cdot 6 \mathrm{H}_{2} \mathrm{O}$ (Wako Pure Chemicals, purity: $>99.9 \%$ ),

$\left[\operatorname{Pd}\left(\mathrm{NH}_{3}\right)_{4}\right] \mathrm{Cl}_{2} \cdot \mathrm{xH}_{2} \mathrm{O}$ (N.E. CHEMCAT, $\mathrm{Pd}: 40.16 \%$ ), and $\left[\mathrm{Pt}\left(\mathrm{NH}_{3}\right)_{4}\right] \mathrm{Cl}_{2} \cdot \mathrm{xH}_{2} \mathrm{O}$ (N.E.

CHEMCAT, Pt: 55.71\%). The impregnated samples were dried at $110{ }^{\circ} \mathrm{C}$ for $12 \mathrm{~h}$ and then

calcined at $300{ }^{\circ} \mathrm{C}(\mathrm{Pd}, \mathrm{Pt}$ catalyst $)$ or $450{ }^{\circ} \mathrm{C}(\mathrm{Co}, \mathrm{Ni}$ catalyst $)$ for $4 \mathrm{~h}$ in static air. The metal

loading of these catalysts was 1 mass $\%(\mathrm{Pd}, \mathrm{Pt})$ or 20 mass\% $(\mathrm{Co}, \mathrm{Ni})$ on a $\mathrm{SiO}_{2}$ weight basis

(as metallic). A commercial $\mathrm{CoMo} / \mathrm{Al}_{2} \mathrm{O}_{3}$ catalyst was used as a sulfided catalyst.

\subsection{Catalyst characterization}

The specific surface area of the support was determined by $\mathrm{N}_{2}$ physisorption using a surface area analyzer (BELSORP-28SA, BEL Japan, Inc.). Prior to the analysis, the sample was heated overnight under vacuum, at $200{ }^{\circ} \mathrm{C}$ to eliminate the volatile species adsorbed on the surface.

Metal dispersions of the catalysts were analyzed on the basis of the amount of chemisorbed $\mathrm{CO}$, which was measured using a pulse method (Ohkura Riken, R-6015). The catalysts were reduced in situ in a $\mathrm{H}_{2}$ stream, at $300{ }^{\circ} \mathrm{C}\left(\mathrm{Pd}\right.$, Pt catalyst) or $450{ }^{\circ} \mathrm{C}(\mathrm{Co}, \mathrm{Ni}$ catalyst), for $4 \mathrm{~h}$, followed by purging with $\mathrm{He}$ at the same temperature for $3 \mathrm{~min}$, then cooling to $50{ }^{\circ} \mathrm{C}$. Subsequent to these pretreatments, a sequential $10 \% \mathrm{CO} / \mathrm{He}$ pulse was injected into the sample at $50{ }^{\circ} \mathrm{C}$ until no more $\mathrm{CO}$ was adsorbed onto the sample.

The acidity of the catalysts was investigated by $\mathrm{NH}_{3}$ adsorption using an $\mathrm{NH}_{3}$ 
calorimeter (CSA-450G, Tokyo Riko Co., Ltd.). The catalysts were evacuated at $300{ }^{\circ} \mathrm{C}$ for 2 $\mathrm{h}$ and cooled to $50{ }^{\circ} \mathrm{C}$ to measure the heat of $\mathrm{NH}_{3}$ adsorption on the acid moieties.

\subsection{Catalytic testing of guaiacol or woody tar}

The HDO reaction was carried out in a small $(80 \mathrm{ml})$ batch reactor. $0.137 \mathrm{~g}$ of the calcined catalyst was charged into the pre-reactor and then reduced in a stream of $\mathrm{H}_{2}$ (purity: $>99.995 \%)$ at $300\left(\mathrm{Pd}, \mathrm{Pt}\right.$ catalyst) or $400{ }^{\circ} \mathrm{C}(\mathrm{Co}, \mathrm{Ni}$ catalyst $)$ for $4 \mathrm{~h}$. Only the commercial $\mathrm{CoMo} / \mathrm{Al}_{2} \mathrm{O}_{3}$ catalyst was sulfided at $360{ }^{\circ} \mathrm{C}$ for $2 \mathrm{~h}$ in a stream of $5 \% \mathrm{H}_{2} \mathrm{~S} / \mathrm{H}_{2}$. These pretreatment conditions were suitable for each catalyst. After pretreatment, the respective catalysts were charged into the batch reactor with $5.48 \mathrm{~g}$ of reactant $[5 \%$ guaiacol (Sigma, purity: $>99 \%$ ) $/ n$-tetradecane (Aldrich, purity $>99 \%$ ), 5\% phenol (Sigma-Aldrich, purity: $>99.5 \%$ ) $/$-tetradecane (Aldrich, purity: $>99 \%$ ), 5\% benzene (Wako chemicals, purity: $>99.5 \%$ ) $/ n$-tetradecane (Aldrich, purity: >99\%), 5\% Cyclohexene (Wako chemicals, purity: $>99 \%$ ) $/ n$-tetradecane (Aldrich, purity: $>99 \%$ ) or $50 \%$ woody tar (Naratanka Kogyo Co., Ltd.)/n-hexadecane (Aldrich, purity: >99\%)] in a glove box. Hydrogen gas (purity: $>99.995 \%$ ) was then charged into the batch reactor at an initial pressure of $1-5 \mathrm{MPa}$. The batch reactor was heated to $300-350{ }^{\circ} \mathrm{C}$ and maintained at that temperature for $1-3 \mathrm{~h}$.

The compounds in the liquid phase were identified using a GC/MS (6890N/5795; 
Agilent Technologies) equipped with an HP-1 fused silica capillary column $(50 \mathrm{~m} \times 0.2 \mathrm{~mm}$,

film thickness of $0.11 \mu \mathrm{m})$. The temperature profile was as follows: heating for $3 \mathrm{~min}$ at a constant temperature of $40{ }^{\circ} \mathrm{C}$, subsequent heating to $200{ }^{\circ} \mathrm{C}$ at $5{ }^{\circ} \mathrm{C} / \mathrm{min}$ and to $320{ }^{\circ} \mathrm{C}$ at $10{ }^{\circ} \mathrm{C} / \mathrm{min}$, and then maintaining the temperature at $320^{\circ} \mathrm{C}$ for $10 \mathrm{~min}$. Quantification of the compounds was performed with a GC/FID (6890N; Agilent Technologies) equipped with an HP-1 fused silica capillary column $(60 \mathrm{~m} \times 0.25 \mathrm{~mm}$, film thickness of $0.25 \mu \mathrm{m})$. The temperature profile used was as follows: constant heating for $3 \mathrm{~min}$ at $40{ }^{\circ} \mathrm{C}$, subsequent heating to $200{ }^{\circ} \mathrm{C}$ at $5{ }^{\circ} \mathrm{C} / \mathrm{min}$ and to $320{ }^{\circ} \mathrm{C}$ at $10{ }^{\circ} \mathrm{C} / \mathrm{min}$, and then maintaining the temperature at $320{ }^{\circ} \mathrm{C}$ for $30 \mathrm{~min}$. The guaiacol conversion and the product distribution were calculated from analysis of the liquid phase. The conversion, rate of deoxygenation, and yield for each experiment were calculated as follows:

GUA conversion $(\%)=\left(1-\frac{n_{G U A}^{\text {final }}}{n_{G U A}^{0}}\right) \times 100$
$\operatorname{HDO}(\%)=\left(1-\frac{n_{\text {Alcohol }}+n_{\text {Ketone }}+n_{\text {phenol }}+n_{\text {others }}}{2 \times n_{G U A}^{0}}\right) \times 100$

where $n_{G U A}^{0}$ is the initial amount of guaiacol (mol), $n_{G U A}^{\text {final }}$ is the final amount of guaiacol (mol), $n_{i}$ is the amount of $i$ (alcohol, ketone, phenol, and others) product at the exit of the reactor. 


\section{Results and discussion}

\subsection{Catalyst characterization}

The characteristics of the catalysts were evaluated on the basis of BET-surface area analysis, $\mathrm{CO}$-chemisorption, and $\mathrm{NH}_{3}$-adsorption. The surface area of the catalysts is shown

in Table 1. The surface area of $\mathrm{Ni} / \mathrm{SiO}_{2}$ and $\mathrm{Co} / \mathrm{SiO}_{2}$ was clearly lower than that of $\mathrm{Pd} / \mathrm{SiO}_{2}$ and $\mathrm{Pt} / \mathrm{SiO}_{2}$, which is attributed to blocking of the small pores of $\mathrm{Ni} / \mathrm{SiO}_{2}$ and $\mathrm{Co} / \mathrm{SiO}_{2}$ given that the metal loadings of $\mathrm{Ni} / \mathrm{SiO}_{2}$ and $\mathrm{Co} / \mathrm{SiO}_{2}$ were higher compared to that of the $\mathrm{Pd} / \mathrm{SiO}_{2}$ and $\mathrm{Pt} / \mathrm{SiO}_{2}$ samples. The dispersion of the metal on the surface of the catalyst is recorded in

Table 1. Notably, the metal dispersion followed a trend similar to that of the surface area of the catalysts. The dispersion of $\mathrm{Ni} / \mathrm{SiO}_{2}$ and $\mathrm{Co} / \mathrm{SiO}_{2}$ was clearly lower than that of $\mathrm{Pd} / \mathrm{SiO}_{2}$ and $\mathrm{Pt} / \mathrm{SiO}_{2}$. Fig. 1 shows the heats of adsorption of $\mathrm{NH}_{3}$ on the various catalysts versus the amounts of $\mathrm{NH}_{3}$ adsorbed, as determined via $\mathrm{NH}_{3}$ calorimetry. The extent of adsorption of small basic molecules (such as $\mathrm{NH}_{3}$ ) is commonly used to determine the number and strength of the acid sites present in the catalysts [25]. The strengths of the acid sites of the catalysts were determined by classifying the catalysts into one of the following categories on the basis of their heats of adsorption: weakly acidic (70-90 kJ/mol), moderately acidic (90-110 kJ/mol), strongly acidic ( $>110 \mathrm{~kJ} / \mathrm{mol})$, and totally acidic ( $>70 \mathrm{~kJ} / \mathrm{mol})$ sites [26-29]. Table 1 shows the 
number of totally acidic sites present in the catalysts, expressed as $\mathrm{mmol} \mathrm{NH}_{3} / \mathrm{g}$-catalyst. The results demonstrate that the total amount of acidic sites increased in the following order: $\mathrm{Co} / \mathrm{SiO}_{2} \square \mathrm{Ni} / \mathrm{SiO}_{2}<\mathrm{Pt} / \mathrm{SiO}_{2}<\mathrm{Pd} / \mathrm{SiO}_{2}$. The acidity of $\mathrm{Pt} / \mathrm{SiO}_{2}$ and $\mathrm{Pd} / \mathrm{SiO}_{2}$ was higher than that of $\mathrm{Co} / \mathrm{SiO}_{2}$ and $\mathrm{Ni} / \mathrm{SiO}_{2}$. This may be because the acidity of the two former catalysts was promoted by $\mathrm{Cl}$. However, the acidity of these catalysts is clearly lower than that of other acid catalysts such as zeolite and $\mathrm{Al}_{2} \mathrm{O}_{3}$ catalysts.

\subsection{Hydrodeoxygenation of guaiacol on several catalysts}

The HDO activity and selectivity of the reduced catalysts were investigated in the

present study in order to elucidate the effect of metal species supported by $\mathrm{SiO}_{2}$ on the production of aromatic hydrocarbon fractions in particular. Several types of products were formed during the HDO reaction, and were classified as shown in Scheme 1. Only the main products generated in this study are shown.

The performance results of the HDO reaction using $5 \mathrm{wt} \%$ guaiacol/tetradecane over $\mathrm{SiO}_{2}$ supported catalysts with different metals are shown in Table 2 . These reactions were carried out at $300{ }^{\circ} \mathrm{C}$, for $1 \mathrm{~h}$, under $5 \mathrm{MPa}$ hydrogen pressure. Under the stated reaction conditions, complete guaiacol conversion was achieved with almost all of the catalysts, with 
the exception of $\mathrm{Pt} / \mathrm{SiO}_{2}$. However, the main product from the conventional sulfided $\mathrm{CoMo} / \mathrm{Al}_{2} \mathrm{O}_{3}$ catalyst was phenol along with small amounts of benzene and cyclohexane. Thus, it can be deduced that the percentage HDO was low. The main products obtained with the reduced $\mathrm{Ni} / \mathrm{SiO}_{2}$ catalysts were cyclohexanol and cyclohexane, indicating that the percentage HDO was similarly not high. However, almost of all the oxygen compounds were deoxygenated in the case of the $\mathrm{Co} / \mathrm{SiO}_{2}, \mathrm{Pt} / \mathrm{SiO}_{2}$, and $\mathrm{Pd} / \mathrm{SiO}_{2}$ catalysts, although the main product was cyclohexane. In particular, the $\mathrm{Co} / \mathrm{SiO}_{2}$ catalyst appears to be effective for guaiacol HDO reaction.

To increase the selectivity towards aromatic compounds, the HDO reactions were carried out at $300{ }^{\circ} \mathrm{C}$, for $1 \mathrm{~h}$, under $1 \mathrm{MPa}$ hydrogen pressure (Table 3). The products of aromatic ring condensation (cyclohexylphenol and cyclohexylcyclohexanol) were detected under these reaction conditions and classified as "Others" in Table 3. The conventional sulfided $\mathrm{CoMo} / \mathrm{Al}_{2} \mathrm{O}_{3}$ catalyst was not highly active for guaiacol conversion under $1 \mathrm{MPa}$ hydrogen pressure, and phenol was the main product obtained with this catalyst. It is thought that the phenol conversion reaction was limited when carried out over the sulfided $\mathrm{CoMo} / \mathrm{Al}_{2} \mathrm{O}_{3}$ catalyst. High guaiacol conversion was achieved with the reduced $\mathrm{Co} / \mathrm{SiO}_{2}$, $\mathrm{Ni} / \mathrm{SiO}_{2}$, and $\mathrm{Pd} / \mathrm{SiO}_{2}$ catalysts. However, cyclohexane and cyclohexanol were the main 
products obtained with the $\mathrm{Ni} / \mathrm{SiO}_{2}$ and $\mathrm{Pd} / \mathrm{SiO}_{2}$ catalysts. Thus, the percentage $\mathrm{HDO}$ and the selectivity for benzene were not particularly high when the reaction was performed over these two catalysts. Although the lowest guaiacol conversion was obtained with the $\mathrm{Pt} / \mathrm{SiO}_{2}$ catalyst, the $\operatorname{HDO}(\%)$ and the yield of cyclohexane were nevertheless higher than those obtained with the sulfided $\mathrm{CoMo} / \mathrm{Al}_{2} \mathrm{O}_{3}$ catalyst. Complete guaiacol conversion was achieved only with the $\mathrm{Co} / \mathrm{SiO}_{2}$ catalyst, and the production of benzene was predominant under reaction conditions of temperature: $300{ }^{\circ} \mathrm{C}$, pressure: $1 \mathrm{MPa}$, and reaction time: $1 \mathrm{~h}$.

Fig. 2 shows the temporal evolution of the product yields and guaiacol conversion for the sulfided $\mathrm{CoMo} / \mathrm{Al}_{2} \mathrm{O}_{3}$ and reduced $\mathrm{Co} / \mathrm{SiO}_{2}$ catalysts. In the case of the sulfided $\mathrm{CoMo} / \mathrm{Al}_{2} \mathrm{O}_{3}$ catalyst, the main reaction product was phenol, and the yields of benzene and cyclohexane were minor. In the previous study, it was reported that conversion of guaiacol to phenol can occur via two mechanisms. Guaiacol can undergo demethylation to form catechol, which is subsequently deoxygenated to form phenol, or guaiacol can undergo demethoxylation to form phenol directly without the catechol intermediate. Based on the present results, it appears that demethoxylation reactions occurred, given that catechol formation was not observed. Further, benzene and cyclohexane were the reaction products obtained using the reduced $\mathrm{Co} / \mathrm{SiO}_{2}$ catalyst, whereas the yields of other oxygenated 
compounds were minor, given that the guaiacol conversion was very high. With increasing guaiacol conversion, the aromatics/naphthenes formation ratio decreased, although the yield of both species increased.

\subsection{Effect of guaiacol content on sulfided $\mathrm{CoMo} / \mathrm{Al}_{2} \mathrm{O}_{3}$ and reduced $\mathrm{Co} / \mathrm{SiO}_{2}$ catalyst for}

\section{HDO reaction}

In general, a large amount (about $40 \%$ ) of oxygenated compounds is present in bio-oil, the effect of which is anticipated to be very critical for catalyst activity and selectivity.

Therefore, the HDO activity and the selectivity of the reduced $\mathrm{Co} / \mathrm{SiO}_{2}$ and sulfided $\mathrm{CoMo} / \mathrm{Al}_{2} \mathrm{O}_{3}$ catalysts were evaluated while varying the guaiacol content from 5 to $20 \mathrm{wt} \%$ in order to investigate the effects of the oxygen content.

The reaction performance results obtained using 5-20 wt\% guaiacol/tetradecane over the reduced $\mathrm{Co} / \mathrm{SiO}_{2}$ and sulfided $\mathrm{CoMo} / \mathrm{Al}_{2} \mathrm{O}_{3}$ catalysts are shown in Table 4. As the guaiacol content increased from 5 to $20 \mathrm{wt} \%$, the guaiacol conversion decreased rapidly from 77.9 to $36.3 \%$ over the sulfided $\mathrm{CoMo} / \mathrm{Al}_{2} \mathrm{O}_{3}$ catalyst, and the $\mathrm{HDO}(\%)$ also decreased from 48.2 to $23.8 \%$. However, the selectivity of this catalyst did not show a meaningful change, and phenol was the main product of the reaction over the sulfided $\mathrm{CoMo} / \mathrm{Al}_{2} \mathrm{O}_{3}$ catalyst. In 
the previous study, it was reported that sulfur removal occurred on sulfided catalysts during the HDO reaction, and the catalyst activity was gradually lost. However, by including a sulfur agent such as $\mathrm{H}_{2} \mathrm{~S}$ in the reaction feed, the sulfided catalyst could be continuously replenished and its activity could be maintained [30]. Nevertheless, unlike petroleum, bio-oil does not contain a significant amount of sulfur. Furthermore, the presence of oxygen-containing compounds has a negative impact on the reaction rate of deoxygenation owing to competitive adsorption of sulfur- and oxygen-containing compounds on the sulfided catalyst [11]. In this study, that influence is found to be remarkable, particularly under highly concentrated oxygen conditions.

In contrast, the guaiacol conversion decreased slightly from $100 \%$ to $82.7 \%$ when the reaction was performed over the reduced $\mathrm{Co} / \mathrm{SiO}_{2}$ catalyst, and the $\mathrm{HDO}(\%)$ decreased from $96.4 \%$ to $78.8 \%$ as the guaiacol content was increased from 5 to $20 \mathrm{wt} \%$. Moreover, the guaiacol content had almost no impact on the selectivity of this catalyst. Even if the reduced catalyst was oxidized by oxygen-containing compounds during the HDO reaction, the catalyst could be continuously replenished by supplying hydrogen, thereby maintaining the activity. Based on these results, the reduced $\mathrm{Co} / \mathrm{SiO}_{2}$ catalyst is deemed useful for the HDO reaction even in the presence of a high oxygen content. 
3.4. Effect of several reactants on sulfided $\mathrm{CoMo} / \mathrm{Al}_{2} \mathrm{O}_{3}$ and reduced $\mathrm{Co} / \mathrm{SiO}_{2}$ catalyst for HDO reaction

The HDO activity and selectivity of the reduced catalysts was evaluated for several reactants (phenol, benzene, and cyclohexene) in order to elucidate the reaction pathway of this HDO reaction (Table 5, 6). Limited conversion was achieved over the sulfided $\mathrm{CoMo} / \mathrm{Al}_{2} \mathrm{O}_{3}$ catalyst using phenol as reactant, and the main products were cyclohexane, cyclohexanol, and benzene. Complete phenol conversion was achieved using the reduced $\mathrm{Co} / \mathrm{SiO}_{2}$ catalyst, with benzene and cyclohexane as the main products. Further, cyclohexene was readily transformed to cyclohexane under these reaction conditions over both of the aforementioned catalysts, whereas benzene was not readily transformed to cyclohexane. Based on these results, it is deduced that benzene was formed via direct deoxygenation of phenol over the reduced $\mathrm{Co} / \mathrm{SiO}_{2}$ catalyst rather than via dehydrogenation of cyclohexene and cyclohexane, under the given reaction conditions.

\subsection{Hydrodeoxygenation of woody tar over several catalysts}

The HDO reactions of real bio-oil (woody tar) were carried out at $350{ }^{\circ} \mathrm{C}$, for $3 \mathrm{~h}$, 
under $5 \mathrm{MPa}$ hydrogen pressure using several catalysts. Table 7 shows the properties of bio-oil (i.e., pH value, water content, and elemental analysis), and the results of the reaction performances using several catalysts are shown in Fig. 3. The index of aromatics refers to the ratio of benzene+toluene+ethylbenzene yields to bezene+toluene+ethylbenzene+cyclohexane+methycyclohexane+ethy-cyclohexane $\quad$ yields The trend of the specific HDO activity over the reduced $\mathrm{SiO}_{2}$ supported and sulfided $\mathrm{CoMo} / \mathrm{Al}_{2} \mathrm{O}_{3}$ catalysts followed the order: $\mathrm{Ni} / \mathrm{SiO}_{2}>\mathrm{Pd} / \mathrm{SiO}{ }_{2}, \mathrm{Co} / \mathrm{SiO}_{2}>>\mathrm{CoMo} / \mathrm{Al}_{2} \mathrm{O}_{3}$ $>\mathrm{Pt} / \mathrm{SiO}_{2}$. However, the specific aromatics selectivity (index of aromatics) over these catalysts followed the trend: $\mathrm{Co} / \mathrm{SiO}_{2}>>\mathrm{CoMo} / \mathrm{Al}_{2} \mathrm{O}_{3}>\mathrm{Pd} / \mathrm{SiO}_{2}>\mathrm{Pt} / \mathrm{SiO}_{2}>\mathrm{Ni} / \mathrm{SiO}_{2}$. With the use of the sulfided $\mathrm{CoMo} / \mathrm{Al}_{2} \mathrm{O}_{3}$ catalyst, the main oxygenated products were phenol-type oxygenated compounds such as phenol, ethylphenol, and trimethylphenol. The sulfided $\mathrm{CoMo} / \mathrm{Al}_{2} \mathrm{O}_{3}$ catalyst was not active for conversion of phenol-type oxygenated compounds compared with the reduced catalysts. Conversely, the $\mathrm{HDO}(\%)$ over the $\mathrm{Ni} / \mathrm{SiO}_{2}$ catalyst was highest, but the index of aromatics was clearly lower than that corresponding to the $\mathrm{Co} / \mathrm{SiO}_{2}$ catalyst. The $\mathrm{Co} / \mathrm{SiO}_{2}$ catalyst exhibited high $\mathrm{HDO}$ activity and the highest aromatic hydrocarbon selectivity for the woody tar HDO reaction. 


\section{Discussion}

Scheme 2 shows the proposed reaction pathway of the guaiacol HDO reaction based

on our results. Laurent and Delmon [14,26] reported the HDO of guaiacol over sulfided

$\mathrm{CoMo} / \mathrm{Al}_{2} \mathrm{O}_{3}$ and $\mathrm{NiMo} / \mathrm{Al}_{2} \mathrm{O}_{3}$ catalysts. Guaiacol is first transformed into catechol via the

demethylation (DME) reaction, followed by the elimination of a catechol hydroxyl group,

forming phenol. Using the current reaction conditions and catalysts, the formation of catechol

was not detected because catechol may be easily converted to phenol when guaiacol is used as

a model feed, although a small amount of catechol formation was observed for the HDO

reaction of woody tar over the conventional sulfided $\mathrm{CoMo} / \mathrm{Al}_{2} \mathrm{O}_{3}$ catalyst. $\mathrm{C}-\mathrm{O}$ bond

breaking of phenol then occurs via deoxygenation of phenol by two different pathways. The

first pathway requires the direct hydrogenolysis of the $\mathrm{C}-\mathrm{O}$ bond between the carbon of the

aromatic and the $\mathrm{OH}$ group (direct deoxygenation; DDO), and the second pathway requires

preliminary hydrogenation of the aromatic ring prior to elimination of the $\mathrm{OH}$ groups

(hydrogenation; HYD). The final products are benzene and cyclohexane. Benzene is suitable

as an alternative fuel to gasoline because it has a high octane number. However, many studies

have reported that phenol is converted to cyclohexane via the HYD route rather than via the

DDO route over sulfided catalysts as well as noble metal catalysts [18-24]. Consequently, 
benzene was a minor product in these studies. However, the reduced $\mathrm{Co} / \mathrm{SiO}_{2}$ catalyst used in this study exhibited high benzene selectivity. It was confirmed that phenol was converted to benzene via the DDO route using the reduced $\mathrm{Co} / \mathrm{SiO}_{2}$ catalyst based on the difficulty to produce benzene from cyclohexene under the current reaction conditions (Table 6).

The dehydration step has been reported to be catalyzed by an acid site [31]. The catalysts used in this study and the reduced $\mathrm{Co} / \mathrm{SiO}_{2}$ catalyst in particular hardly demonstrated acidic properties. Olcese and co-workers reported that $\mathrm{Fe} / \mathrm{SiO}_{2}$ showed high aromatic selectivity in the HDO reaction of guaiacol, similar to the current observations using $\mathrm{Co} / \mathrm{SiO}_{2}$ [32]. They proposed that $\mathrm{Fe}$ is a poor hydrogenating metal for the aromatic ring relative to nickel or precious metals $[33,34]$. Silica is poorly acidic compared to alumina [8] or certain zeolites [35] and consequently lowers coke deposit from oxygenated aromatic hydrocarbon conversion $[8,36]$. Furthermore, in the guaiacol molecule, the $n$-electrons of the oxygen atoms are more basic than the $\pi$-electrons of the $\mathrm{C}=\mathrm{C}$ aromatic system. It is thus expected that the adsorption occurs on the weakly acidic silica $\mathrm{OH}$ sites by interaction with the $\mathrm{O}$ atoms (in the hydroxyl or methoxy groups) rather than with the aromatic ring. This activation favors $\mathrm{C}-\mathrm{O}$ bond breaking at the expense of $\mathrm{C}-\mathrm{C}$ bond breaking. The chemical mechanisms are catalyzed in the presence of supported iron metal particles that supply the active $\mathrm{H}$-species 
coming from the dissociation of $\mathrm{H}_{2}$ molecules on the metal phase. The results of this study support their suggestion. The mechanisms are illustrated in Scheme 3, taking into account the findings of Olcese et al. [32] and Popov et al. [37].

\section{Conclusion}

The upgrading of model bio-oils (guaiacol and woody tar) was studied using various reduced catalysts in a small batch reactor, at an $\mathrm{H}_{2}$ pressure of 1-5 $\mathrm{MPa}$, in the temperature range of $300-350{ }^{\circ} \mathrm{C}$. The evaluated catalysts include $\mathrm{Ni} / \mathrm{SiO}_{2}, \mathrm{Co} / \mathrm{SiO}_{2}, \mathrm{Pt} / \mathrm{SiO}_{2}$, and $\mathrm{Pd} / \mathrm{SiO}_{2}$ prepared by incipient wetness impregnation. A conventional hydrodesulfurization $\mathrm{CoMo} / \mathrm{Al}_{2} \mathrm{O}_{3}$ catalyst was evaluated for comparative purposes.

Under temperature and $\mathrm{H}_{2}$ pressure conditions of $300{ }^{\circ} \mathrm{C}$ and $1 \mathrm{MPa}$, higher guaiacol conversion was achieved with the reduced $\mathrm{Co} / \mathrm{SiO}_{2}, \mathrm{Ni} / \mathrm{SiO}_{2}$, and $\mathrm{Pd} / \mathrm{SiO}_{2}$ catalysts than with the conventional sulfide $\mathrm{CoMo} / \mathrm{Al}_{2} \mathrm{O}_{3}$ catalyst. Cyclohexanol and phenol were the major products obtained with the reduced $\mathrm{Ni} / \mathrm{SiO}_{2}$ and $\mathrm{Pd} / \mathrm{SiO}_{2}$ catalysts. High $\mathrm{HDO}$ activity and selectivity for aromatics was achieved in the guaiacol HDO reaction using the reduced $\mathrm{Co} / \mathrm{SiO}_{2}$ catalyst. Good $\mathrm{HDO}$ performance and aromatic selectivity were also achieved at a high guaiacol content and for woody tar feed, using the reduced $\mathrm{Co} / \mathrm{SiO}_{2}$ catalyst. It is 
postulated that one of the underlying reasons for the good performance of this catalyst is the fact that the reduced $\mathrm{Co} / \mathrm{SiO}_{2}$ catalyst exhibited high activity for the DDO reaction of phenol, yielding mostly benzene. This study is one of the first steps in the rational design of more active and stable HDO catalysts for fast pyrolysis oils.

\section{Acknowledgement}

This research was supported by JST/JICA, Science and Technology Research Partnership for Sustainable Development (SATREPS), Japan.

\section{References}

[1] A. Demirbas, Progr. Energ. Combust. Sci. 31 (2005) 466.

[2] R.P. Anex, A. Aden, F.K. Kazi, J. Fortman, R.M. Swanson, M.M. Wright, J.A. Satrio, R.C. Brown, D.E. Daugaard, A.Platon, G.Kothandaraman, D.D. Hsu, A. Dutta, Fuel 89 (2010) S29.

[3] A.V. Bridgwater, S. Czrnik, J. Piskorz, in: A.V. Bridgwater (Ed.), Fast Pyrolysis of Biomass: A Handbook, Antony Rowe Ltd., Chippenham, UK, 2002, pp. 1.

[4] D. Mohan, C.U. Pittman, P. Steele, Energy Fuels 20 (2006) 848.

[5] E. Furimsky, F.E. Massoth, Catal. Today 52 (1999) 381.

[6] T.C. Ho, Catal. Today 98 (2004) 3.

[7] E. Furimsky, Appl. Catal. A 199 (2000) 147. 
[8] A. Centeno, E. Laurent, B. Delmon, J. Catal. 154 (1995) 288.

[9] G. de la Puente, A. Gil, J.J. Pis, P. Grange, Langmuir 15 (1999) 5800.

[10]D.C. Elliot, G.G. Neuenschwander, T.R. Hart, J. Hu, A.E. Solana, C. Cao, in: A.V. Bridgwater, D.G.B. Boocock (Eds.), Science in Thermal and Chemical Biomass Conversion, vol. 2, CPL Scientific Ltd., Newbury, 2006, p. 1536.

[11]E. Furimsky, F.E. Massoth, Catal. Today 52 (1999) 381.

[12]A. Bridgwater, Appl. Catal. A 116 (1994) 5.

[13]A.V. Bridgwater, Catal. Today 29 (1996) 285.

[14]E. Laurent, B. Delmon, Appl. Catal. A 109 (1994) 97.

[15] S.R.A. Kersten, W.P.M. van Swaaij, L. Lefferts, K. Seshan, in: G. Centi, R.A. van Santen (Eds.), Catalysis for Renewables-From Feedstocks to Energy Production, Wiley-VCH, Weinheim, 2007, p. 119 (Chapter 6).

[16]B.M. Reddy, A. Khan, Catal. Rev. 47 (2005) 257.

[17]A. Popov, E. Kondratieva, J.P. Gilson, L. Mariey, A. Travert, F. Maugé, Catal. Today 172 (2011) 132.

[18]J.B-son Bredenberg, M. Huuska, P. Toropainen, J. Catal. 120 (1989) 401.

[19]T. Nimmanwudipong, R.C. Runnebaum, D.E. Block, and B.C. Gates, Energy Fuels 25 (2011) 3417.

[20]E.M. Ryymin, M.L. Honkela, T.R. Viljava, A.O.I. Krause, Appl. Catal. A 389 (2010) 114. [21]A. Gutierrez, R.K. Kaila, M.L. Honkela, R. Slioor, A.O.I. Krause, Catal. Today 147 
(2009) 239.

[22]C. Sepúlveda, K. Leiva, R. García, L.R. Radovic, I.T. Ghampson, W.J. DeSisto, J.L. García Fierro, N. Escalona, Catal. Today 172 (2011) 232.

[23]C. Zhao, Y. Kou, A.A. Lemonidou, X. Li and J.A. Lercher, Angew. Chem., Int. Ed. 48 (2009) 2987.

[24]N. Yan, Y. Yuan, R. Dykeman, Y. Kou and P.J. Dyson, Angew. Chem., Int. Ed. 49 (2010) 5549.

[25]M. Niwa, M. Kato, T. Hattori, Y. Murakami, J Phys Chem-Us 90 (1986) 6233.

[26] J.H. Kim, Y. Sugi, T. Matsuzaki, T. Hanaoka, Y. Kubota, X. Tu, M. Matsumoto, S. Nakata, A. Kato, G. Seo, C. Pak, Appl Catal a-Gen 131 (1995) 15.

[27]T. Mochizuki, M. Toba, Y. Morita, Y. Yoshimura, J Jpn Petrol Inst 51 (2008) 315.

[28]N. Numwong, A. Luengnaruemitchai, N. Chollacoop, Y. Yoshimura, J Am Oil Chem Soc 89 (2012) 2117.

[29]N. Numwong, A. Luengnaruemitchai, N. Chollacoop, Y. Yoshimura, Appl Catal a-Gen $441(2012) 72$.

[30] V.N. Bui, G. Toussaint, D. Laurenti, C. Mirodatos, C. Geantet, Catal. Today 143 (2009) 172.

[31]H. Zhao, D. Li, P. Bui, S. Oyama, Appl. Catal. A 391 (2011) 305.

[32]R.N. Olcese, M. Bettahar, D. Petitjean, B. Malaman, F. Giovanella, A. Dufour, Appl. Catal. B 115-116 (2012) 63. 
[33]P. Emmett, N. Skau, J. Am. Chem. Soc. 65 (1943) 1029.

[34]K. Yoon, A. Vannice, J. Catal. 82 (1983) 457.

[35]C. Perego, S. Amarilli, A. Carati, C. Flego, G. Pazzuconi, C. Rizzo, G. Bellussi, Microporous Mesoporous Mater. 27 (1999) 345.

[36] E.-J. Shin, M. Keane, Ind. Eng. Chem. Res. 39 (2000) 883.

[37]A. Popov, E. Kondratieva, J. Goupil, L. Mariey, P. Bazin, J. Gilson, A. Travert, F. Mauge, J. Phys. Chem. C 114 (2010) 15661. 


\section{Figure Caption}

Fig. 1 Acidity levels of the catalysts investigated as catalysts.

Fig. 2 Evolution of product yields and conversion of guaiacol as a function of time for: (A) sulfided $\mathrm{CoMo} / \mathrm{Al}_{2} \mathrm{O}_{3}$, (B) reduced $\mathrm{Co} / \mathrm{SiO}_{2}$ catalysts at $300^{\circ} \mathrm{C}, 1 \mathrm{MPa}$.

Fig. 3 Reaction performance for $\mathrm{HDO}$ reaction of woody tar at $350^{\circ} \mathrm{C}, 5 \mathrm{MPa}$ and $3 \mathrm{~h}$.

\section{Table Captions}

Table 1 Physical properties of several catalysts in this study.

Table 2 Product yields and conversion for $\mathrm{HDO}$ reaction of guaiacol at $300^{\circ} \mathrm{C}, 5 \mathrm{MPa}$ and $1 \mathrm{~h}$.

Table 3 Product yields and conversion for $\mathrm{HDO}$ reaction of guaiacol at $300^{\circ} \mathrm{C}, 1 \mathrm{MPa}$, and $1 \mathrm{~h}$. 
Table 4 Effect of guaiacol content on HDO reaction of reduced $\mathrm{Co} / \mathrm{SiO}_{2}$ and sulfided $\mathrm{CoMo} / \mathrm{Al}_{2} \mathrm{O}_{3}$ catalysts at $300^{\circ} \mathrm{C}, 1 \mathrm{MPa}$, and $1 \mathrm{~h}$.

Table 5 Product yields and conversion for HDO reaction of several reactants over sulfided $\mathrm{CoMo} / \mathrm{Al}_{2} \mathrm{O}_{3}$ catalyst at $300^{\circ} \mathrm{C}, 1 \mathrm{MPa}$ and $1 \mathrm{~h}$.

Table 6 Product yields and conversion for HDO reaction of several reactants over reduced $\mathrm{Co} / \mathrm{SiO}_{2}$ catalyst at $300^{\circ} \mathrm{C}, 1 \mathrm{MPa}$ and $1 \mathrm{~h}$.

Table 7 Properties and element compositions of woody tar.

\section{Scheme Captions}

Scheme 1 Main products of guaiacol HDO reaction identified by GC/MS.

Scheme 2 Reaction scheme for Guaiacol conversion. 
Scheme 3 Possible reaction mechanism of guaiacol conversion into aromatic hydrocarbons

by $\mathrm{HDO}$ over $\mathrm{Co} / \mathrm{SiO}_{2}$. The adsorption of guaiacol was proposed by Olcese et al. [32] and

Popov et al. [37]. 


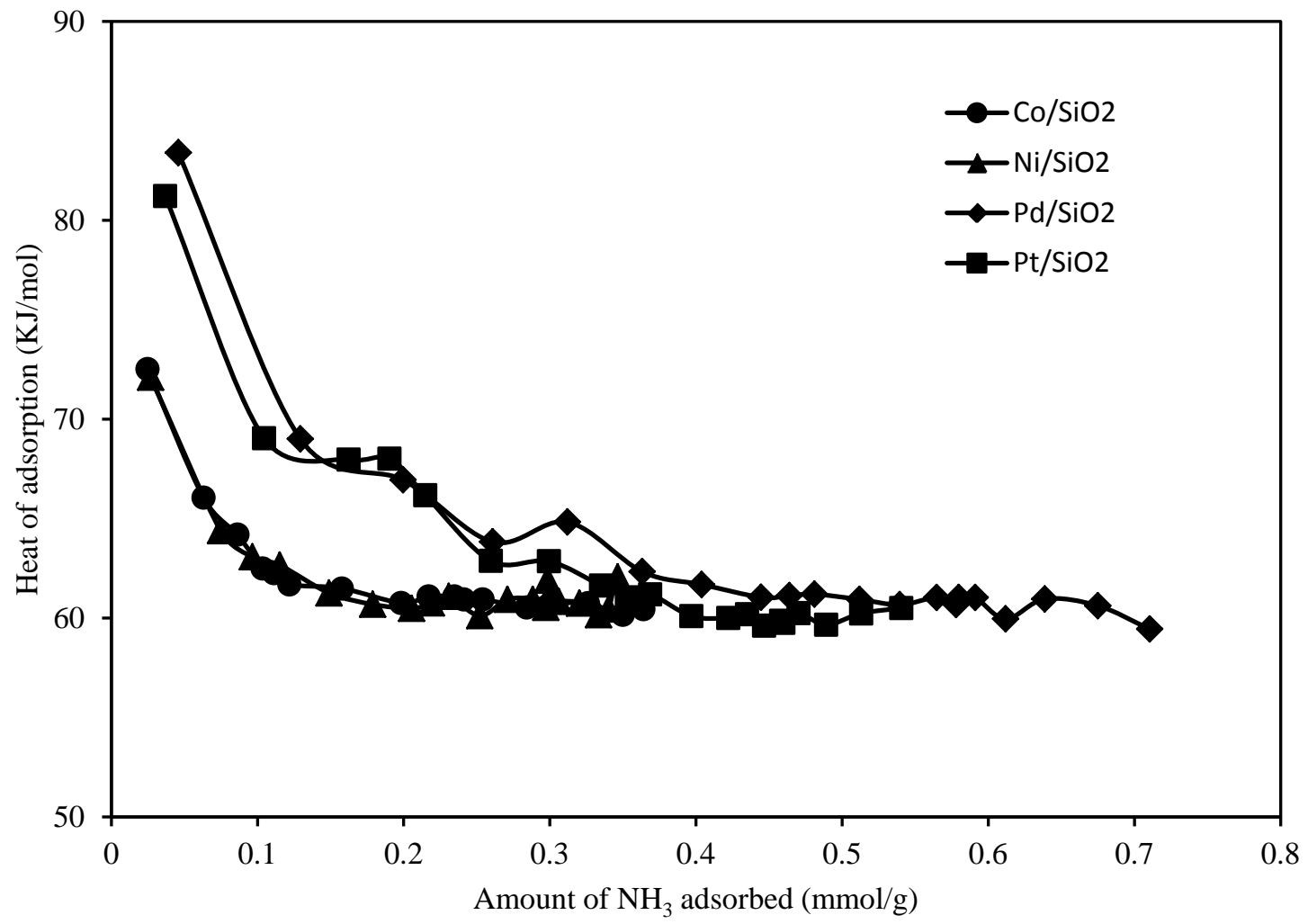

Fig. 1 Acidity levels of the catalysts investigated as catalysts. 

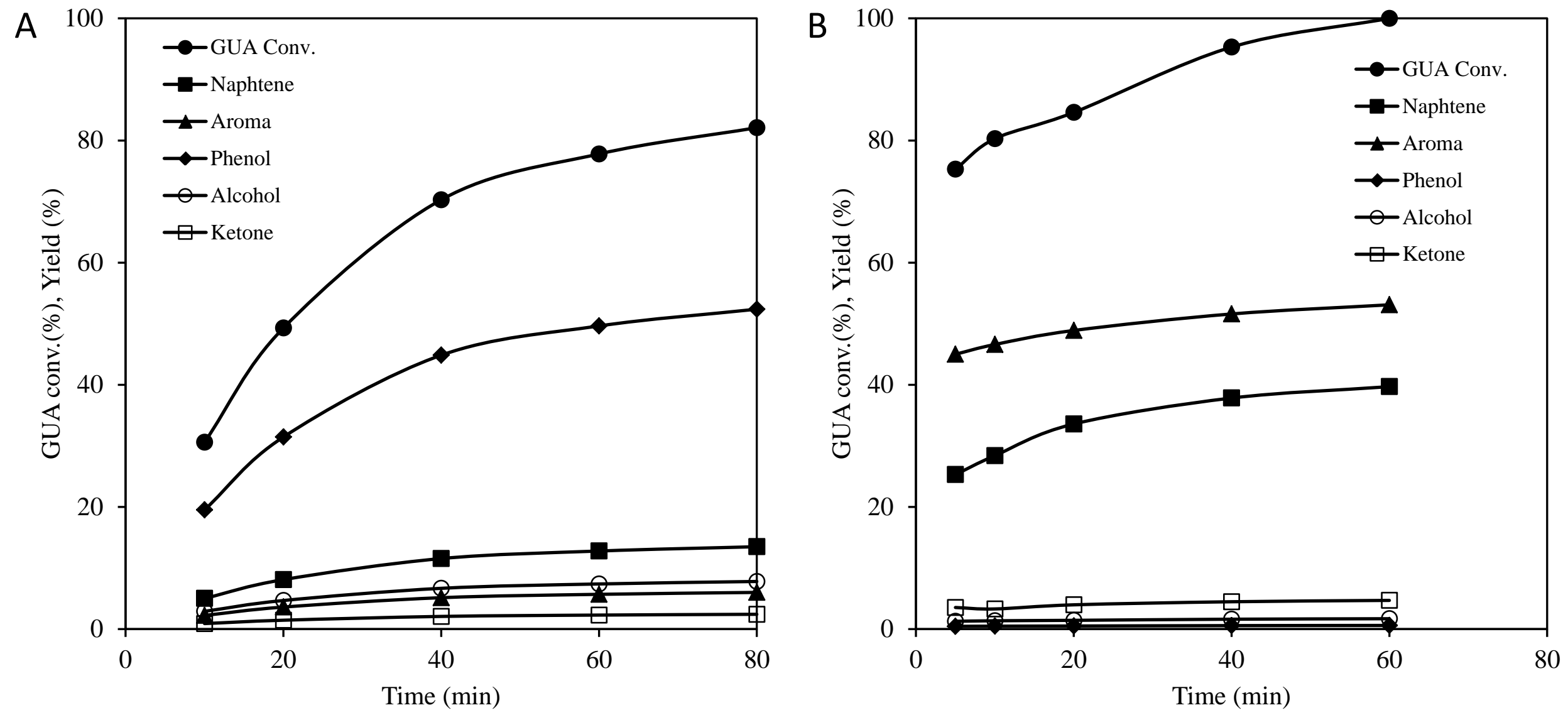

Fig. 2 Evolution of product yields and conversion of guaiacol as a function of time for: (A) sulfided $\mathrm{CoMo} / \mathrm{Al}_{2} \mathrm{O}_{3}$, (B) reduced $\mathrm{Co} / \mathrm{SiO}_{2}$ catalysts at $300^{\circ} \mathrm{C}, 1 \mathrm{MPa}$. 


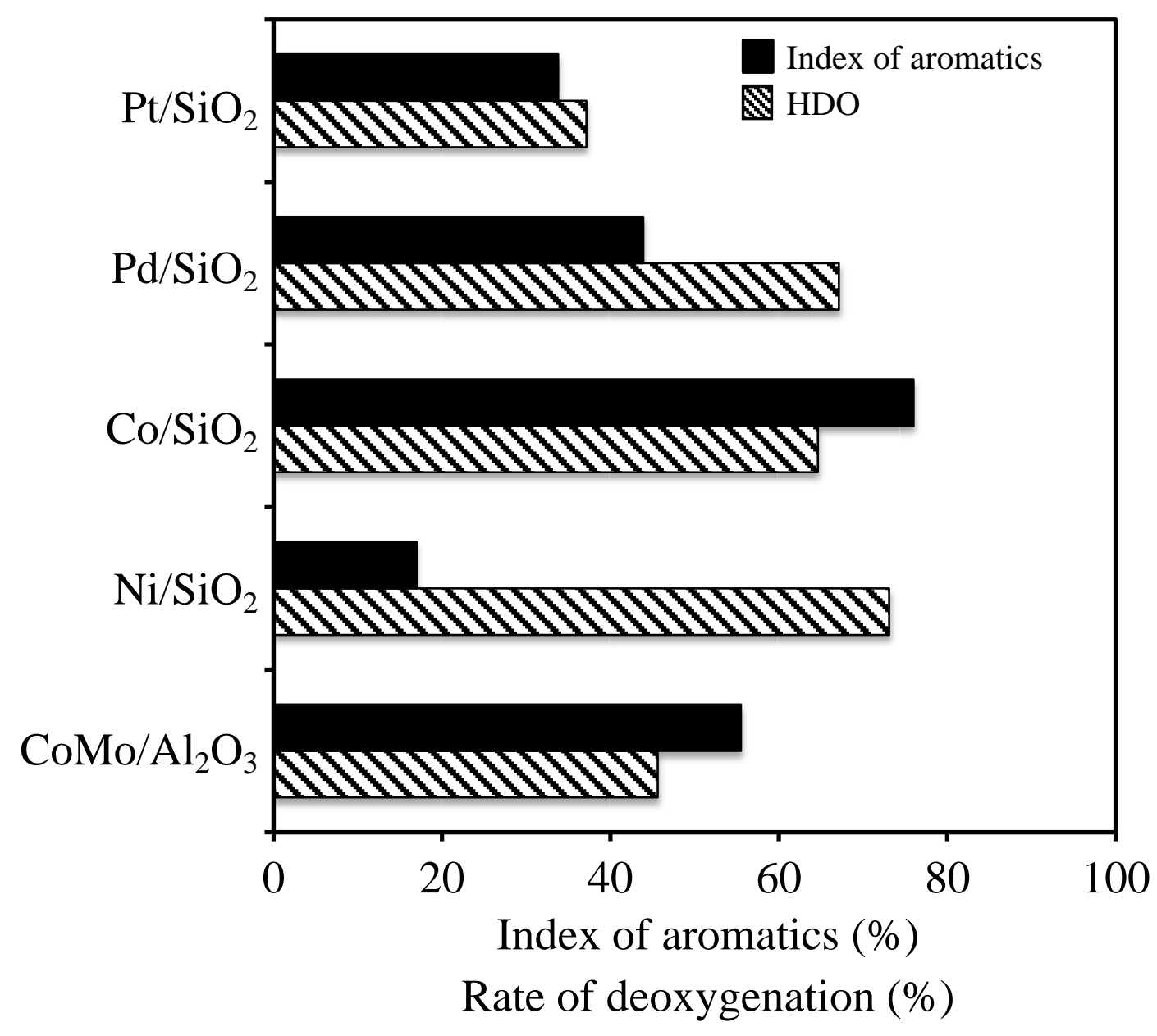

Fig. 3 Reaction performance for HDO reaction of woody tar at $350^{\circ} \mathrm{C}$, $5 \mathrm{MPa}$ and $3 \mathrm{~h}$. 


\section{Deoxygenated compounds}

Aroma<smiles>c1ccccc1</smiles>

Naphtene

\section{Oxygenated compounds}

Alcohol<smiles>OC1CCCCC1</smiles>

Ketone<smiles>O=C1CCCCC1</smiles>

Phenol

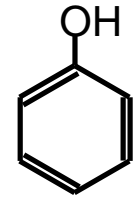

Scheme 1 Main products of guaiacol HDO reaction identified by GC/MS. 


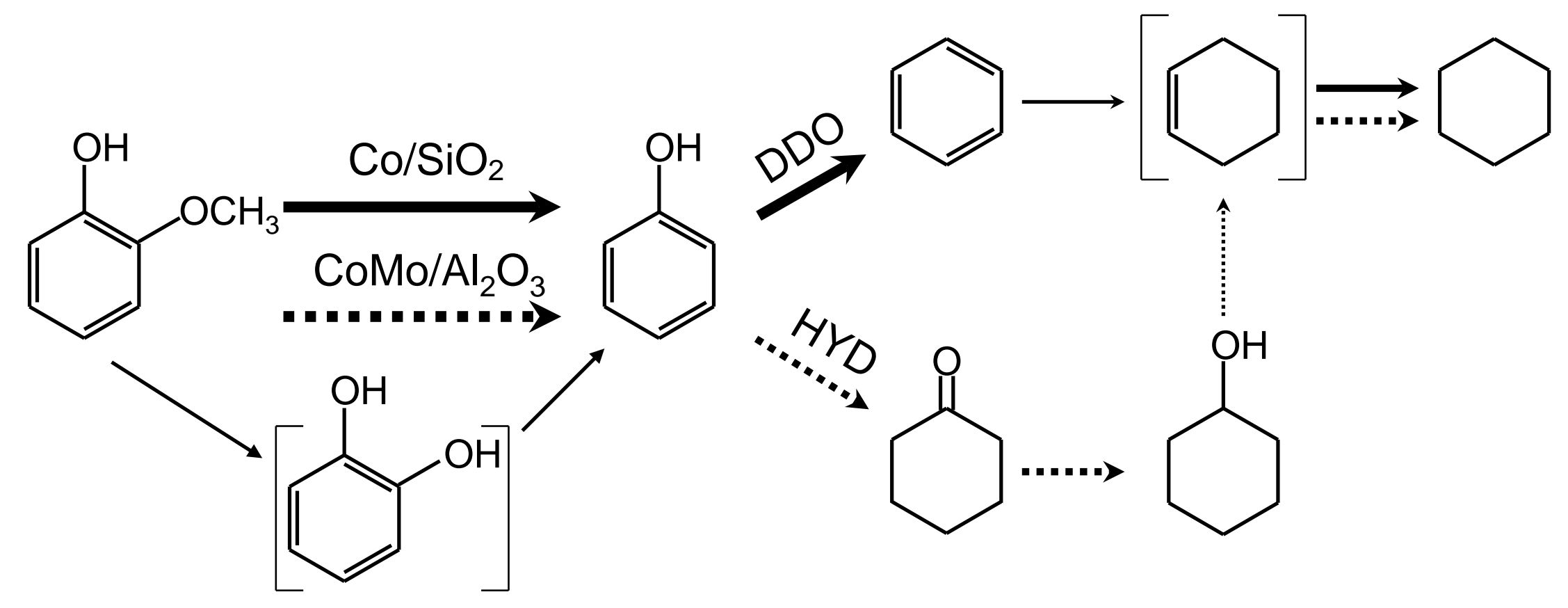

Scheme 2 Reaction scheme for Guaiacol conversion. 


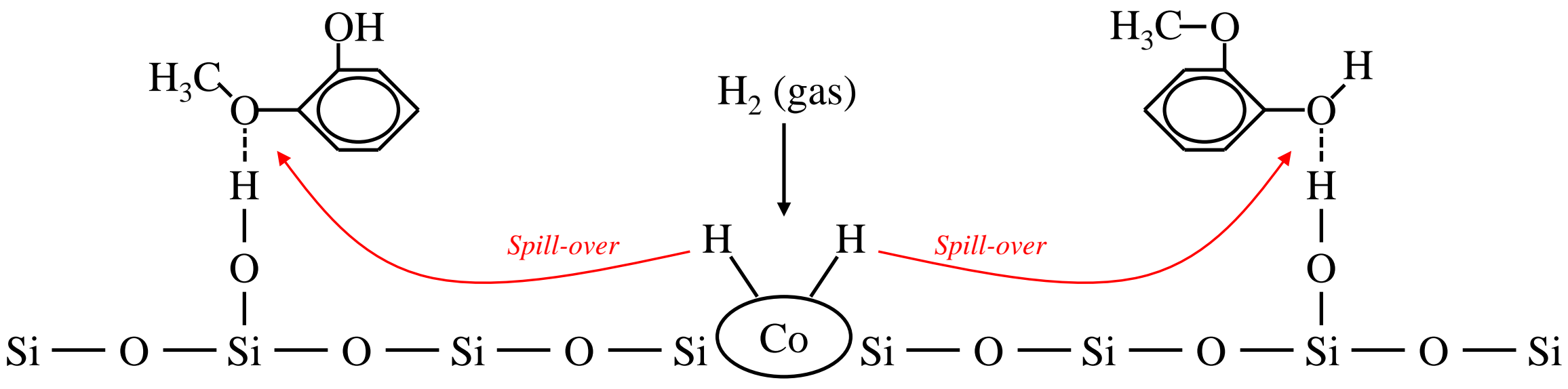

Scheme 3 Possible reaction mechanism of guaiacol conversion into aromatic hydrocarbons by HDO over $\mathrm{Co} / \mathrm{SiO}_{2}$. The adsorption of guaiacol was proposed by Olcese et al. [32]and Popov et al. [37]. 
Table 1 Physical properties of several catalysts in this study.

\begin{tabular}{lcccc}
\hline Catalyst & $\begin{array}{c}\text { Metal loading } \\
(\text { wt } \%)\end{array}$ & $\begin{array}{c}\mathrm{S}_{\mathrm{BET}} \\
\left(\mathrm{m}^{2} \mathrm{~g}^{-1}\right)\end{array}$ & $\begin{array}{c}\text { Dispersion }^{\mathrm{a}} \\
(\%)\end{array}$ & $\begin{array}{c}\text { Acidity }^{\mathrm{b}} \\
\left.\text { (mmol-NH }_{3} / \text { g-cat. }\right)\end{array}$ \\
\hline $\mathrm{CoMo} / \mathrm{Al}_{2} \mathrm{O}_{3}$ & - & 142 & - & - \\
$\mathrm{Ni} / \mathrm{SiO}_{2}$ & 20 & 164 & 3.5 & 0.038 \\
$\mathrm{Co} / \mathrm{SiO}_{2}$ & 20 & 160 & 2.8 & 0.039 \\
$\mathrm{Pd} / \mathrm{SiO}_{2}$ & 1 & 220 & 19.6 & 0.121 \\
$\mathrm{Pt} / \mathrm{SiO}_{2}$ & 1 & 226 & 13.2 & 0.097 \\
\hline
\end{tabular}

${ }^{\mathrm{a}}$ Dispersion was calcurated by amount of CO chemisorption.

${ }^{\mathrm{b}}$ Acidity was measured by $\mathrm{NH}_{3}$ calorimeter. 
Table 2 Product yields and conversion for HDO reaction of guaiacol at $300^{\circ} \mathrm{C}, 5 \mathrm{MPa}$ and $1 \mathrm{~h}$.

\begin{tabular}{lrrrrr}
\hline & $\mathrm{CoMo} / \mathrm{Al}_{2} \mathrm{O}_{3}$ & $\mathrm{Ni} / \mathrm{SiO}_{2}$ & $\mathrm{Co} / \mathrm{SiO}_{2}$ & $\mathrm{Pd} / \mathrm{SiO}_{2}$ & $\mathrm{Pt} / \mathrm{SiO}_{2}$ \\
\hline GUA conversion (\%) & 100 & 100 & 100 & 100 & 98.3 \\
HDO (\%) & 65.5 & 74.7 & 99.9 & 92.0 & 94.8 \\
Yield (\%) & & & & & \\
$\quad$ Naphtene & 13.1 & 49.1 & 98.0 & 74.4 & 89.1 \\
Aroma & 17.9 & 0.3 & 1.7 & 1.5 & 2.3 \\
Alcohol & 5.8 & 50.1 & 0.0 & 10.9 & 5.4 \\
Ketone & 1.8 & 0.0 & 0.2 & 4.5 & 0.5 \\
Phenol & 61.4 & 0.5 & 0.1 & 0.7 & 1.0 \\
\hline
\end{tabular}


Table 3 Product yields and conversion for HDO reaction of guaiacol at $300^{\circ} \mathrm{C}, 1 \mathrm{MPa}$ and $1 \mathrm{~h}$.

\begin{tabular}{lrrrrr}
\hline & $\mathrm{CoMo} / \mathrm{Al}_{2} \mathrm{O}_{3}$ & $\mathrm{Ni} / \mathrm{SiO}_{2}$ & $\mathrm{Co} / \mathrm{SiO}_{2}$ & $\mathrm{Pd} / \mathrm{SiO}_{2}$ & $\mathrm{Pt} / \mathrm{SiO}_{2}$ \\
\hline GUA conversion (\%) & 77.8 & 100 & 100 & 99.3 & 70.9 \\
HDO (\%) & 48.1 & 71.8 & 96.4 & 79.5 & 54.5 \\
Yield (\%) & & & & & \\
$\quad$ Naphtene & 12.8 & 30.4 & 39.7 & 49.3 & 30.2 \\
Aroma & 5.7 & 13.2 & 53.1 & 10.3 & 5.6 \\
Alcohol & 7.4 & 54.1 & 1.7 & 28.4 & 34.2 \\
Ketone & 2.3 & 1.5 & 4.7 & 9.7 & 0.8 \\
Phenol & 49.6 & 0.5 & 0.6 & 0.7 & 0.7 \\
Others & 0.0 & 0.3 & 0.2 & 0.9 & 1.6 \\
\hline
\end{tabular}


Table 4 Effect of guaiacol content on $\mathrm{HDO}$ reaction of reduced $\mathrm{Co} / \mathrm{SiO}_{2}$ and sulfided $\mathrm{CoMo} / \mathrm{Al}_{2} \mathrm{O}_{3}$ catalysts at $300^{\circ} \mathrm{C}, 1 \mathrm{MPa}$ and $1 \mathrm{~h}$.

\begin{tabular}{|c|c|c|c|c|c|c|}
\hline & \multicolumn{6}{|c|}{ Guaiacol content (\%) } \\
\hline & \multicolumn{3}{|c|}{$\mathrm{CoMo} / \mathrm{Al}_{2} \mathrm{O}_{3}$} & \multicolumn{3}{|c|}{$\mathrm{Co} / \mathrm{SiO}_{2}$} \\
\hline & 5 & 10 & 20 & 5 & 10 & 20 \\
\hline GUA conversion (\%) & 77.9 & 63.6 & 36.3 & 100 & 88.8 & 82.7 \\
\hline HDO (\%) & 48.2 & 40.0 & 23.8 & 96.4 & 85.3 & 78.8 \\
\hline \multicolumn{7}{|l|}{ Yield (\%) } \\
\hline Naphtene & 12.8 & 10.3 & 8.3 & 39.7 & 30.7 & 29.8 \\
\hline Aroma & 5.7 & 6 & 3 & 53.1 & 51.1 & 45.1 \\
\hline Alcohol & 7.4 & 7.5 & 4 & 1.7 & 2.6 & 1.7 \\
\hline Ketone & 2.3 & 1.5 & 0.8 & 4.7 & 3.5 & 4.7 \\
\hline Phenol & 49.7 & 38.3 & 20.2 & 0.6 & 0.8 & 1.2 \\
\hline Others & 0 & 0 & 0 & 0.2 & 0.1 & 0.2 \\
\hline
\end{tabular}


Table 5 Product yields and conversion for HDO reaction of several reactants over sulfided $\mathrm{CoMo} / \mathrm{Al}_{2} \mathrm{O}_{3}$ catalyst at $300^{\circ} \mathrm{C}, 1 \mathrm{MPa}$ and $1 \mathrm{~h}$.

Conv. (\%) Main product yield (\%)


Table 6 Product yields and conversion for HDO reaction of several reactants over reduced $\mathrm{Co} / \mathrm{SiO}_{2}$ catalyst at $300^{\circ} \mathrm{C}, 1 \mathrm{MPa}$ and $1 \mathrm{~h}$.

Conv. (\%) Main product yield (\%)


Table 7 Properties and element compositions of woody tar.

\begin{tabular}{lr}
\hline & Woody tar \\
\hline $\mathrm{pH}$ & 2.3 \\
Water content (\%) & 8.3 \\
& \\
Element compositions (wt\%) & 69.2 \\
$\mathrm{C}$ & 7.3 \\
$\mathrm{H}$ & 23.3 \\
$\mathrm{O}$ & 0.2 \\
$\mathrm{~N}$ & $<0.1$ \\
$\mathrm{~S}$ &
\end{tabular}


